\title{
Anthropogenic influence of trace metals in sediments of the Al-Qilt catchment, West Bank, Palestine: 1. Contamination factor and bonding forms
}

\author{
Sobhi Samhan · Kurt Friese • Wolf von Tümpling • \\ Herbert Pöllmann · Heinz Hoetzl • Marwan Ghanem
}

Received: 17 July 2012/Accepted: 15 May 2013/Published online: 2 June 2013

(C) The Author(s) 2013. This article is published with open access at Springerlink.com

\begin{abstract}
Al-Qilt catchment, located east of both the Ramallah and Jerusalem districts is strongly influenced by waste waters discharged from Israeli settlements and Palestinian urban centers. In this research, our aim was to verify the chemical status of the surface sediments from the Al-Qilt catchment during 2008/2009. For this purpose, 36 surface sediment samples were collected and analyzed with ICP/MS within the fraction of below $63 \mu \mathrm{m}$. The extent of contamination of trace metals from Al-Qilt sediments sites were measured by evaluating the contamination factors (CF) from digestion by aqua regia and additionally by sequential extraction steps using the BCR-method. On the basis of the calculated $\mathrm{CF}$, sediments appear particularly contaminated with $\mathrm{Zn}, \mathrm{Cu}, \mathrm{Ag}, \mathrm{Sn}, \mathrm{Cd}, \mathrm{Hg}, \mathrm{Bi}$, and $\mathrm{B}$. Three regions, Wadi Sweanit, Ras Al-Qilt, and Qalandiah have been identified as critical points of contamination. Trace metal inputs to the Al-Qilt catchment need to be kept under strict control in the future since Ras Al-Qilt is considered as one of the important springs in the area and is used for domestic purposes. Moreover, it will be susceptible to pollution if no action is taken to decrease the pollution at the upstream of Al-Qilt.
\end{abstract}

S. Samhan $(\bowtie) \cdot$ K. Friese $\cdot$ W. von Tümpling Department Lake Research, UFZ-Helmholtz Centre for Environmental Research, Magdeburg, Germany

e-mail: subhisamhan@yahoo.com

H. Pöllmann

Institute of Geosciences, Martin-Luther-University

of Halle-Wittenberg, Halle, Germany

H. Hoetzl

University of Karlsruhe (UKA), Karlsruhe, Germany

M. Ghanem

Palestinian Hydrological Group (PHG), West Bank, Palestine
Keywords Contamination factors - BCR method . Fractionation · Al-Qilt catchment

\section{Introduction}

For long time, the water from the Al-Qilt catchment was used for drinking purposes, irrigation, and washing. Today, more than 65,000 people from Palestinian communities (PCBS 2005) and six Israeli colonies totaling to about 15,000 people (PCBS 2003) live in the Al-Qilt catchment. From the wastewater which discharges to the catchment less than $10 \%$ is treated efficiently in the West Bank, whereas most of it discharge untreated into the open environment to the nearest wadis (ARIJ 2007). The wastewater discharge in the Al-Qilt catchment is estimated to about $9,500 \mathrm{~m}^{3} /$ day from the Palestinian communities and to about $4,500 \mathrm{~m}^{3} / \mathrm{day}$ from the Israeli colonies, totaling to about $14,000 \mathrm{~m}^{3} /$ day of wastewater treated and untreated. The wastewater which is treated at the Al-Bireh wastewater treatment plant is subsequently mixed with raw wastewater from Qalandiah and runs downstream. To examine the chemical status, water samples were taken within a monitoring program twice a year for the hydrochemical analyses of major elements $\left(\mathrm{Ca}, \mathrm{Mg}, \mathrm{Na} \mathrm{K}, \mathrm{SO}_{4}\right.$, $\mathrm{NO}_{3}, \mathrm{Cl}$, and $\mathrm{HCO}_{3}$ ) and physical parameters such as, $\mathrm{pH}$, temperature, and turbidity (PWA 2009). Other parameters such as heavy metals that cause pollution due to anthropogenic parameters were analyzed within some special investigation programs for limited studies (PWA 2009).

Based on that knowledge, sediments samples from AlQilt catchment were taken to assign the anthropogenic pollution by heavy metals and arsenic. Calculations were done using the average shale values of Turekian and Wedepohl (1961) and by soil samples from Al-Qilt as 
references. Moreover, the soils from Al-Bireh, Fawwar, Ras Al-Qilt, and Murashahat were taken as representative reference values since these regions are located far away from human activities and considered as pristine areas within the catchment. Based on these values, the contamination factors were calculated and evaluated for the total contents as well as for sequential fractionation steps that represent the bonding group and speciation of trace metals. These fractionation steps are important for understanding the release and transport of heavy metals within the local environment.

The size of the Al-Qilt drainage catchment is about $174 \mathrm{~km}^{2}$ (Fig. 1) and it is situated in the east of the West Bank. Al-Qilt's most important tributaries by lengths are Wadi Al-Ein $(7.5 \mathrm{~km})$, Wadi Mukhmas $(9 \mathrm{~km})$, Qalandiah $(2 \mathrm{~km})$, and Stone Cut $(2 \mathrm{~km})$ which are all located at the left, northern bank of the catchment. The study area is characterized by a steep relief with elevations ranging from 800 m.a.s.l. at the western part to -250 m.b.s.l. at the eastern part. Moreover; the rainfall is estimated by $600 \mathrm{~mm} / \mathrm{a}$ at the western part and it is $150 \mathrm{~mm} / \mathrm{a}$ at the eastern part, and the average rainfall over the catchment is about $400 \mathrm{~mm} / \mathrm{a}$ (PWA 2009).

A 50-km long stretch of Wadi Al-Qilt east of both Ramallah and Jerusalem districts and west of the Jordan
Valley has been selected for the present study. Freshly deposited and grab sediment samples were collected from Al-Qilt during June and October 2008 and in June and October of 2009 (Fig. 1). Moreover, nine sites were selected to represent the following type of sediments (1) sediments from effluents of treated waste water (Al-Bireh waste water treatment plant), (2) sediments from untreated waste water (Qalandiah and Stone Cut), (3) sediments from wadis that carry waste water and runoff (Mukhmas and Sweanit), and (4) sediments from freshwater (springs such as Fawwar, Ras Al-Qilt, Murashahat, and Sultan).

The aim of this study was to evaluate the quality of the sediment according to trace elements at Al-Qilt catchment to identify contaminated sites. For these sites, the extent of degradation of the ecosystem and environmental should be estimated. This can be achieved by studying the following factors:

1. Calculation of the Contamination Enrichment Factor (CF) for the "aqua regia" fraction to assess the extent of metal pollution and their distribution

2. Calculation of the Contamination Factor (CF) for each step within a sequential extraction scheme (BCRmethod, Ure et al. 1993) to get information about the relevance of the different bonding forms

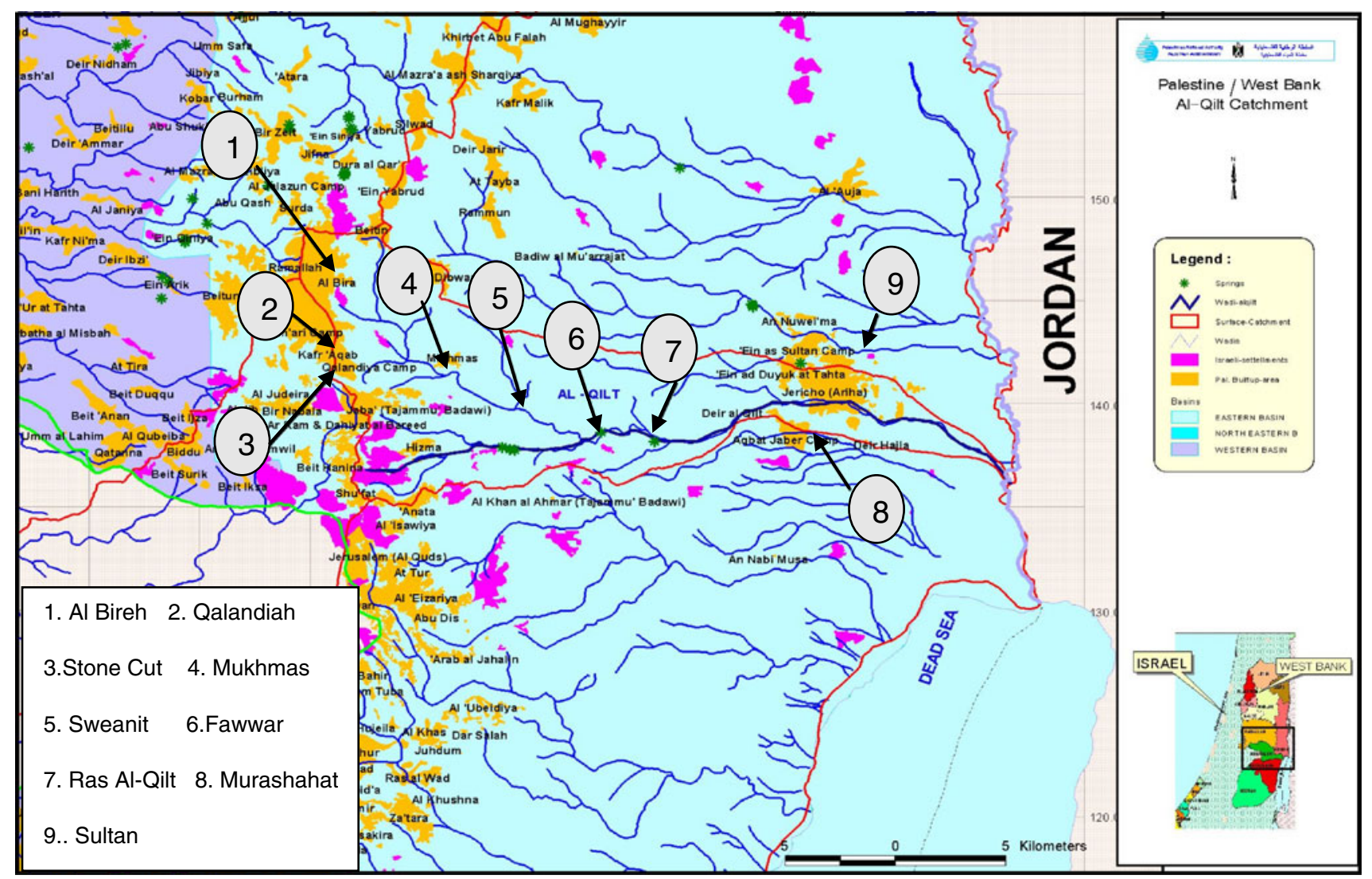

Fig. 1 Study area of Al-Qilt catchment, Springs, distance between sampling sites and major cities (Palestinian Water Authority 2009) 
3. Relating the $\mathrm{CF}$ to $\mathrm{BCR}$ fractionation as a tool for mobility and transport of trace metals

\section{Materials and methods}

The collected sediment samples were taken using a plastic grab "non-metallic" sampler to take small batched samples from beneath the top surface $(3-5 \mathrm{~cm})$. The $250 \mathrm{ml}$ plastic bottles (Jar) were then preserved at $4^{\circ} \mathrm{C}$ for analysis.

In the laboratory, the sediment samples were frozen to $-25^{\circ} \mathrm{C}$ to stop microbial activity before they were submitted to "freeze-drying and evaporation" using a CHRIST Delta 1-24 LSC for 4 days. Afterwards, about 200-250 g of the dry material was sieved into $63 \mu \mathrm{m}$ sub-samples using the sieving unit Fritsch D-55743.

For total digestion, about $0.25 \mathrm{~g}$ from the homogenized samples and from the Buffalo sediment Standard Reference Material (SRM 8704) were weighted into $100 \mathrm{ml}$ Teflon digestion tubes and added with $6 \mathrm{ml}$ of concentrated $\mathrm{HNO}_{3}$ (65\%) and $3 \mathrm{ml}$ of concentrated $\mathrm{HCl}(37 \%)$. Afterwards, the samples were digested for $2 \mathrm{~h}$ using a Microwave (MARS 5) digester. Thereafter, the samples were adjusted with high purity water to $25 \mathrm{ml}$ for analysis. Trace metal contents were measured for $\mathrm{Cr}, \mathrm{Co}, \mathrm{Ni}, \mathrm{Cu}, \mathrm{Zn}, \mathrm{As}, \mathrm{Sr}, \mathrm{Mo}$, Ag, Cd, Sn, Sb, Ba, Pb, Bi, and B using a Agilent 7500 ICP-MS Inductive Coupled Plasma Mass Spectrometer and for $\mathrm{Hg}$ using a Flow Injection Mercury System (FIMS 400, Perkin Elmer). Samples were analyzed according to Water and Wastewater Standard Methods (APHA 2000) and according to the German Standard Methods for the examination of water, waste water, and sludge (DIN 38414, 1984) methods.

The methodology used for sequential extraction is based on the BCR-method (Ure et al. 1993). About $1 \mathrm{~g}$ of the sieved sediment and soil samples $(<63 \mu \mathrm{m})$ from the Certified Reference Material (CRM BCR-701) were weighted into glass tubes. Table 1 summarizes the subsequent 4 step procedure.
To describe the degree of pollution of a given parameter, the contamination factor is used here as the ratio of the sediment metal content at a given sampling location and the reference value of the respective element (local soil or continental crust value). The Contamination Factor (CF) is expressed as:

$\mathrm{CF}=\frac{C o}{C b}$

where $C o$ is the mean content of a given element in the sediment, $C b$ is the reference value for the respective element

The contamination factor was classified into four groups according to Hokanson (1980) and Pekey et al. (2004). They used the following terminology: $C f<1$ for low contamination; $1 \leq C \mathrm{f}<3$ for moderate contamination; $3 \leq C \mathrm{f}<6$ for considerable contamination; and $C \mathrm{f} \geq 6$ for very high contamination.

For quality control and quality assurance, the precision and accuracy of the data were checked through repeated analysis $(n=5)$ using the international standard for sediment such as Buffalo sediment Standard Reference Material (SRM 8704) for total digestion and the Certified Reference Material (CRM 701) for BCR fractionation steps. The results were within $\pm 15 \%$ of the certified values for sediment samples, whereas the recovery of most of the elements was within range of acceptance (80-110\%) with the exception of barium $(61 \%)$.

\section{Results and discussion}

Soil and continental crust as reference values

In this study, we used the pristine soil samples from Sweanit, Fawwar, Ras Al-Qilt, and Murashahat and the continental crust values from Turekian and Wedepohl (1961) as reference values for the calculations. There is an agreement between soil and continental crust values for $\mathrm{Cr}$, $\mathrm{Ni}, \mathrm{Cu}, \mathrm{Sr}, \mathrm{Sn}$, and $\mathrm{Pb}$; on the other hand, the soil reference
Table 1 Reagents and conditions employed for the (BCR) sequential extraction procedure

\begin{tabular}{|c|c|c|}
\hline Step & Fraction & Reagent and conditions \\
\hline 1 & Exchangeable & $\begin{array}{l}1 \mathrm{~g} \text { of samples, BCR Ref (701) and } 40 \mathrm{ml} 0.11 \mathrm{~mol} \mathrm{l}^{-1} \mathrm{CH}_{3} \mathrm{COOH} \text {, shaken for } 16 \mathrm{~h} \\
\text { at room temperature, centrifuged } 3,000 \times g \text { for } 20 \mathrm{~min} \text {, decant the supernatant, } \\
\text { wash the solid, centrifuge then go to the next step }\end{array}$ \\
\hline 2 & Reducible & $\begin{array}{l}40 \mathrm{ml} 0.5 \mathrm{~mol} \mathrm{l} \mathrm{l}^{-1} \mathrm{NH}_{2} \mathrm{OH} \cdot \mathrm{HCl} \text {, shaken } 16 \mathrm{~h} \text { at room temperature, centrifuged as in } \\
\text { step 1, then the supernatant for analysis }\end{array}$ \\
\hline 3 & Oxidizable & $\begin{array}{l}\text { Digested with } 10 \mathrm{ml} 8.8 \mathrm{~mol} \mathrm{l}^{-1} \mathrm{H}_{2} \mathrm{O}_{2}, 1 \mathrm{~h} \text { at room temperature, } 1 \mathrm{~h} \text { at } 85{ }^{\circ} \mathrm{C} \text { and } \\
\text { covered samples, } 10 \mathrm{ml} 8.8 \mathrm{~mol} \mathrm{l}^{-1} \mathrm{H}_{2} \mathrm{O}_{2} \text { added, } 1 \mathrm{~h} \text { at } 85{ }^{\circ} \mathrm{C} \text {, reduced volume to } \\
1 \mathrm{ml} \text {, extracted with } 50 \mathrm{ml} \text { of } 1 \mathrm{~mol} \mathrm{l}^{-1} \mathrm{NH}_{4} \mathrm{COOCH}_{3}, \mathrm{pH} \text { of solution } 2-3 \text {, } \\
\text { shaken } 16 \mathrm{~h} \text { at room temperature }\end{array}$ \\
\hline 4 & Residual & $\begin{array}{l}9 \mathrm{ml} 12 \mathrm{~mol} \mathrm{l}^{-1} \mathrm{HCl}, 3 \mathrm{ml} 16 \mathrm{~mol} \mathrm{l}^{-1} \mathrm{HNO}_{3} \text {, Microwave digestion for } 2 \mathrm{~h} \text {, cool, } \\
\text { decant the supernatant, centrifuge, then sample for analysis }\end{array}$ \\
\hline
\end{tabular}


values for $\mathrm{Zn}, \mathrm{As}, \mathrm{Ag}, \mathrm{Mo}, \mathrm{Hg}$, and $\mathrm{Cd}$ are higher and for Ba lower than the continental crust values. These variations will affect the calculations for the contamination factor and is important to identify the agreement and disagreement between the soil and continental crust as reference values (Fig. 2).
Contamination factor $(\mathrm{CF})$ calculated from total contents

The results for both the continental crust and soil reference values are shown in Table 2. According to the contamination factor classifications done by Hokanson (1980),

Fig. 2 Soil reference versus continental crust values (median, minimum, and maximum)

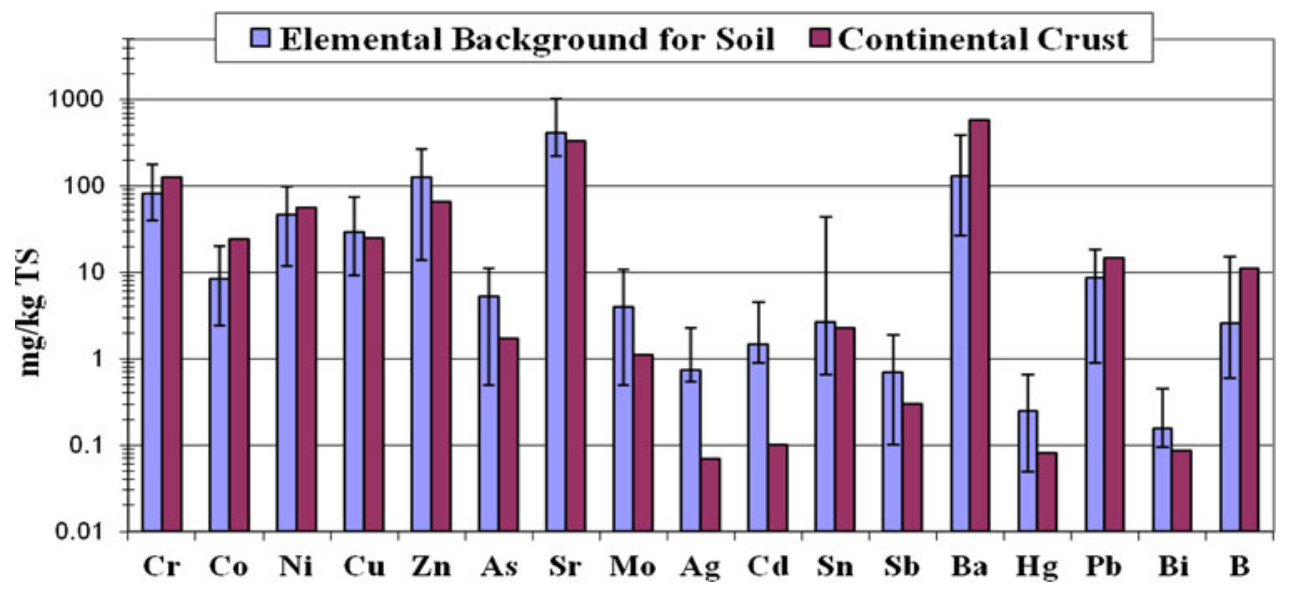

Table 2 Contamination factors trace metals at the Al-Qilt catchment using the Soil Reference (SR) and Continental Crust (CC)

\begin{tabular}{|c|c|c|c|c|c|c|c|c|c|c|c|c|c|c|c|c|c|}
\hline Sampling Sites & $\mathrm{Cr}$ & Co & $\mathrm{Ni}$ & $\mathrm{Cu}$ & Zn & As & $\mathrm{Sr}$ & Mo & Ag & Cd & Sn & $\mathbf{S b}$ & $\mathbf{B a}$ & $\mathrm{Hg}$ & $\mathbf{P b}$ & $\mathbf{B i}$ & B \\
\hline SR & 82.8 & 8.3 & 47.5 & 29 & 126.9 & 5.4 & 410.5 & 4 & 0.8 & 1.5 & 2.7 & 0.7 & 132 & 0.2 & 8.7 & 0.2 & 2.6 \\
\hline ALBireh & 0.9 & 1.1 & 0.8 & 3.3 & 5.3 & 1 & 0.4 & 1 & 29.3 & 0.5 & 3.1 & 3.3 & 1.4 & 14.7 & 4.8 & 12.5 & 8.5 \\
\hline Mukhmas & 0.9 & 1.1 & 0.8 & 3.3 & 5.3 & 1 & 0.5 & 0.8 & 29.3 & 0.5 & 2.8 & 2.3 & 1.4 & 6.8 & 4.1 & 8 & 5 \\
\hline Qalandiah & 0.9 & 0.9 & 1 & 5.5 & 3.8 & 0.7 & 0.4 & 0.7 & 2.9 & 0.6 & 3 & 1.9 & 1.4 & 3.3 & 3.9 & 6.8 & 2.4 \\
\hline Stone Cut & 0.9 & 0.7 & 0.8 & 1.4 & 1.4 & 0.9 & 0.7 & 1 & 1.6 & 0.6 & 1.6 & 2.2 & 1.7 & 1 & 6.1 & 2.5 & 1.8 \\
\hline Sweanit & 0.7 & 0.6 & 0.6 & 2.5 & 4.5 & 0.7 & 0.6 & 1.2 & 23.2 & 0.5 & 5.1 & 1.6 & 1.9 & 0.9 & 1.9 & 9.1 & 6.4 \\
\hline Fawwar & 1 & 0.8 & 0.9 & 1.7 & 2.7 & 1 & 0.9 & 1.3 & 13.1 & 1 & 2.9 & 1.7 & 1.4 & NM & 1.5 & 4.1 & 6.2 \\
\hline Ras Al-Qilt & 0.9 & 0.7 & 1 & 0.9 & 1.2 & 0.9 & 1.3 & 1.3 & 2.7 & 2 & 1.1 & 1.2 & 1.4 & 0.8 & 0.8 & 1.1 & 1.5 \\
\hline Murashahat & 0.9 & 0.8 & 0.8 & 1.4 & 0.7 & 1.1 & 0.9 & 1.1 & 0.8 & 0.6 & 0.9 & 0.7 & 0.8 & 0.2 & 1 & 3.6 & 10.1 \\
\hline Sultan & 0.7 & 1.1 & 0.6 & 0.8 & 0.7 & 0.5 & 0.6 & 0.3 & 0.3 & 1 & 4 & 0.4 & 0.4 & $\mathrm{NM}$ & 2 & 0.4 & 0.8 \\
\hline
\end{tabular}

\begin{tabular}{|c|c|c|c|c|c|c|c|c|c|c|c|c|c|c|c|c|c|}
\hline Sampling Sites & $\mathrm{Cr}$ & Co & $\mathrm{Ni}$ & $\mathrm{Cu}$ & Zn & As & $\mathrm{Sr}$ & Mo & Ag & Cd & Sn & $\mathbf{S b}$ & Ba & Hg & $\mathbf{P b}$ & Bi & B \\
\hline $\mathrm{CC}$ & 126 & 24 & 56 & 25 & 65 & 1.7 & 333 & 1.1 & 0.1 & 0.1 & 2.3 & 0.3 & 584 & 0.1 & 14.8 & 0.1 & 11 \\
\hline ALBireh & 0.6 & 0.4 & 0.7 & 3.9 & 10.3 & 3.1 & 0.5 & 3.5 & 314.3 & 6.9 & 3.5 & 7.7 & 0.3 & 55 & 2.8 & 23.5 & 4.2 \\
\hline Mukhmas & 0.5 & 0.4 & 0.6 & 3.4 & 8.9 & 2.5 & 0.6 & 3 & 283.8 & 7.4 & 4.4 & 5.3 & 0.3 & 13.5 & 2.1 & 16.1 & 2.2 \\
\hline Qalandiah & 0.6 & 0.3 & 0.8 & 6.4 & 7.4 & 2.1 & 0.5 & 2.6 & 31.4 & 9 & 3.5 & 4.3 & 0.3 & 12.5 & 2.3 & 12.8 & 0.6 \\
\hline Stone Cut & 0.6 & 0.2 & 0.7 & 1.6 & 2.7 & 2.8 & 0.8 & 3.7 & 17.1 & 8.8 & 1.9 & 5.1 & 0.4 & 3.6 & 3.6 & 4.7 & 0.4 \\
\hline Sweanit & 0.5 & 0.2 & 0.5 & 2.9 & 8.8 & 2.1 & 0.7 & 4.3 & 248.6 & 7.3 & 5.9 & 3.7 & 0.4 & 3.5 & 1.1 & 17.1 & 1.5 \\
\hline Fawwar & 0.6 & 0.3 & 0.8 & 2 & 5.2 & 3.3 & 1.1 & 4.6 & 140 & 14.7 & 3.4 & 4 & 0.3 & $\mathrm{NM}$ & 0.9 & 7.6 & 1.5 \\
\hline Ras Al-Qilt & 0.6 & 0.2 & 0.9 & 1 & 2.2 & 2.8 & 1.6 & 4.7 & 28.6 & 30.1 & 1.2 & 2.7 & 0.3 & 2.8 & 0.5 & 2.1 & 0.3 \\
\hline Murashahat & 0.6 & 0.3 & 0.7 & 1.7 & 1.3 & 3.4 & 1.5 & 3.9 & 8.6 & 9.1 & 1 & 1.7 & 0.2 & 0.7 & 0.6 & 6.7 & 1.5 \\
\hline Sultan & 0.5 & 0.4 & 0.5 & 0.9 & 1.4 & 1.5 & 0.7 & 1.2 & 2.9 & 15.4 & 4.7 & 1 & 0.1 & NM & 1.2 & 0.8 & 0.2 \\
\hline
\end{tabular}

All values were calculated based on medium values $n=36$

$\mathrm{CF}<1$ in white, $1 \leq \mathrm{CF}<3$ light gray, $3 \leq \mathrm{CF}<6$ gary and $\mathrm{CF} \geq 6$ dark black 
Pekey et al. (2004) and by determining the total contents for $\mathrm{Cr}, \mathrm{Co} \mathrm{Ni}, \mathrm{As}, \mathrm{Sr}, \mathrm{Mo}, \mathrm{Cd}$, and $\mathrm{Ba}$, there are scattered pollution points in sediments. Significantly, they are lower than the continental crust reference values for $\mathrm{As}, \mathrm{Cd}$, and Mo. These results indicate that there are higher contamination factor values for the investigated sediments (Table 2).

The contamination factors for $\mathrm{Sr}, \mathrm{Mo}, \mathrm{Sb}, \mathrm{Ba}, \mathrm{As}, \mathrm{Cr}$, $\mathrm{Co}, \mathrm{Ni}$, and $\mathrm{Cd}$ are classified as moderate contamination to considerable contamination since $1 \leq C \mathrm{f}<6 . \mathrm{Cu}, \mathrm{Zn}, \mathrm{Sn}$, $\mathrm{Pb}, \mathrm{Ag}, \mathrm{Hg}, \mathrm{Bi}$, and $\mathrm{B}$ are classified as very high contaminated because $C f \geq 6$ (acc. to Hokanson 1980, Pekey et al. 2004)

Regarding the sites, the contamination factors at Qalandiah, Al-Bireh, Mukhmas, and Sweanit were high compared with other sites in terms of the number of pollutants that pose the highest values of CFs based on continental crust values.

The very high $\mathrm{CFs}$ for $\mathrm{Ag}, \mathrm{Hg}, \mathrm{Bi}$, and $\mathrm{B}$ appear at $\mathrm{Al}-$ Bireh and at Mukhmas, since the wastewater coming from Al-Bireh is mixed again at Mukhmas with raw wastewater from Qalandiah and Stone Cut. Although the distance from Mukhmas to Sweanit is about 4-5 km, these parameters still have high contamination factors at Sweanit, which means that there must be an additional source in between downstream or these trace elements were transported preferentially as suspended particulate matters downstream.

\section{Contamination factors calculated from sequential extraction}

Results revealed that for the highly enriched $\mathrm{Zn}, \mathrm{Hg}, \mathrm{Bi}, \mathrm{B}$, and $\mathrm{Cu}$, there bonding forms must be taken into consideration for an assessment of the contamination factors. By calculating contamination factors for each step of the BCR fractionation (using SR values), this will give indication for the potential of release and mobility.

The CFs for the BCR fractionation steps and the recovery values were within acceptable $15 \%$ error, except for $\mathrm{Cd}(133 \%)$ and for $\mathrm{Ba}(58 \%)$ (Table 3$)$.

In general, results for total $\mathrm{CFs}$ reveal that $\mathrm{Cr}, \mathrm{Ni}, \mathrm{As}$, $\mathrm{Sr}, \mathrm{Cd}$, and $\mathrm{Ba}$ have CFs less than six and therefore do not pose any risk for contamination of the environments and ecosystems. On the other hand; the $\mathrm{CFs}$ for $\mathrm{Co}, \mathrm{Cu}, \mathrm{Zn}$, $\mathrm{Mo}, \mathrm{Ag}, \mathrm{Sn}, \mathrm{Sb} \mathrm{Pb}$, and $\mathrm{Bi}$ were greater than six for one of the BCR fractionation steps indicating a weak bonding of these trace metals. Moreover, the CFs reflect the potential risk for an easy mobility or transport of these trace metals within the aquatic system. For example, $\mathrm{Zn}$ has the highest values of CFs in the first step of the BCR fractionation at Al-Bireh (treated wastewater), Qalandiah (untreated wastewater), and Fawwar spring (groundwater), suggesting that it was released at this stage since this step is classified as being the most exchangeable fraction which contains metals in loosely held surface associations. Because of the association with "carbonates", these are easy to leach and transport within the aquatic system.

On the other hand, $\mathrm{Co}, \mathrm{Ag}$, and $\mathrm{Cd}$ have the highest values of CFs at step two of the sequential extraction (reducible fraction) at Sultan spring "groundwater", indicating that $\mathrm{Co}$ is released at this stage. Therefore, it is likely that $\mathrm{Co}$ is adsorptive bounded to oxides and oxyhydroxides of $\mathrm{Mn}$ and amorphous $\mathrm{Fe}$.

Furthermore, $\mathrm{Cu}, \mathrm{Zn}, \mathrm{Mo}, \mathrm{Ag}, \mathrm{Sb}, \mathrm{Pb}$, and $\mathrm{Bi}$ have the highest values of CFs at step three (oxidizable fraction) at Al-Bireh, whereas $\mathrm{Cu}, \mathrm{Ag}, \mathrm{Sb}$, and $\mathrm{Bi}$ show the highest values of CFs within this fraction at Mukhmas (wadi for wastewater) and $\mathrm{Cu}, \mathrm{Mo}, \mathrm{Sb}, \mathrm{Pb}$, and $\mathrm{Bi}$ at Qalandiah. The highest $\mathrm{CFs}$ within this fraction were found for $\mathrm{Sb}, \mathrm{Pb}$, and $\mathrm{Bi}$ at Stone Cut and for $\mathrm{Bi}, \mathrm{Ag}, \mathrm{Sn}$, and $\mathrm{Sb}$ at Fawwar spring (groundwater). The display of the highest CFs for these trace elements within the oxidizable fraction relate them to be associated with organic matter and sulfides or that they are occurring in an oxidizable form within the residue.

At least, $\mathrm{Ag}$ and $\mathrm{Bi}$ were predominant within step four (residual fraction) at Al-Bireh, Mukhmas, and Fawwar. This indicates that these elements can be classified as being "residual" and are not available for the environment.

Finally, the results revealed that for $\mathrm{Zn}, \mathrm{Ag}, \mathrm{Pb}$, and $\mathrm{Bi}$, the CFs within all four fractions are high $(>6)$ at different sites. This will increase the risk for mobility and transport within the aquatic system from the residual to the exchangeable fraction. Moreover; the trace element fractionation behaves in different manners at the springs. At Fawwar, the uppermost Al-Qilt spring, Ag is released at steps three and four suggesting that it occurs in oxidizable and residual form, whereas it is released at Ras Al-Qilt spring in steps one and two within the exchangeable "carbonate bonded" and reducible "Fe and Mn bonded" forms. However, at Sultan Spring another situation was observed since $\mathrm{Co}$ and $\mathrm{Pb}$ were released at step two, from the reducible fraction which made it likely that they were bonded to Fe- and/or Mn-oxides/hydroxides. These variations lead to a complex behavior of the trace elements within the unsaturated zone regarding their stability. On the contrary, the $\mathrm{CF}$ s for $\mathrm{Cr}, \mathrm{Ni}, \mathrm{As}, \mathrm{Sr}, \mathrm{Cd}$, and $\mathrm{Ba}$ never exceeded six for all BCR's fractionation steps, which categorize them not to pose impacts at Al-Qilt wadi.

\section{Conclusions}

The surface sediment samples of the Al-Qilt catchment are characterized by trace element contents that are typical of aquatic environments located in industrial and densely 
Table 3 Contamination factors for the BCR fractionation steps at Al-Qilt, units are in $\mathrm{mg} / \mathrm{kg}$ and $n=3$ for each step

\begin{tabular}{|c|c|c|c|c|c|c|c|c|c|c|c|c|c|c|c|}
\hline Sampling sites & $\mathrm{Cr}$ & Co & $\mathbf{N i}$ & $\mathbf{C u}$ & Zn & As & $\mathrm{Sr}$ & Mo & Ag & Cd & Sn & Sb & $\mathbf{B a}$ & $\mathbf{P b}$ & Bi \\
\hline Recovery & 101 & 110 & 111 & & 111 & & & & & 132 & & 111 & 58 & 91 & \\
\hline Al Bireh Step 1 & 0.68 & 2.33 & 1.21 & 2 & 61.61 & 3.08 & 0.92 & 1.25 & 2 & 0.22 & 1 & 3.33 & 0.48 & 5 & 5 \\
\hline Al Bireh Step 2 & 0.27 & 0.5 & 0.57 & 0.78 & 18.18 & 1.5 & 0.38 & 1 & 10 & 0.6 & 1 & 2.5 & 1.62 & 3.53 & 5 \\
\hline Al Bireh Step 3 & 1.73 & 0.68 & 1.34 & 13.55 & 7.05 & 1.43 & 0.38 & 10 & 19 & 1.04 & 1 & 31 & 2.33 & 6.17 & 20 \\
\hline Al Bireh Step 4 & 0.58 & 0.5 & 0.51 & 1.46 & 0.79 & 0.34 & 0.61 & 0.35 & 80.4 & 0.64 & 3.7 & 2.67 & 1.12 & 3.7 & 7.87 \\
\hline Mukhmas Step1 & 0.75 & 3 & 1.42 & 0.6 & 3.23 & 3.04 & 0.96 & 1.25 & 10 & 0.17 & 1 & 3.33 & 1 & 2.5 & 5 \\
\hline Mukhmas Step2 & 0.27 & 0.75 & 0.57 & 0.33 & 3.88 & 1.5 & 0.6 & 1 & 10 & 0.53 & 1 & 2.5 & 1.47 & 1.06 & 5 \\
\hline Mukhmas Step3 & 1.37 & 1.45 & 1.72 & 7.24 & 3 & 1.3 & 1.3 & 2.63 & 9 & 1.46 & 1 & 10 & 2 & 5.78 & 6.2 \\
\hline Mukhmas Step4 & 1.2 & 1.3 & 1.03 & 1.35 & 1.1 & 0.61 & 1.06 & 0.58 & 6.2 & 0.86 & 2.87 & 1.33 & 2.55 & 0.78 & 1.67 \\
\hline Qalandiah Step1 & 0.75 & 5.33 & 3.26 & 1.2 & 34.19 & 1.54 & 0.54 & 2.5 & 2 & 0.33 & 1 & 3.33 & 0.92 & 5 & 1 \\
\hline Qalandiah Step2 & 0.87 & 1 & 1.07 & 0.89 & 8.96 & 3.1 & 0.35 & 1 & 10 & 0.67 & 1 & 5 & 1.04 & 15.88 & 5 \\
\hline Qalandiah Step3 & 1.12 & 0.9 & 1.52 & 33.71 & 5.42 & 2.27 & 0.49 & 6.32 & 5 & 1.18 & 2 & 20 & 1.58 & 16.64 & 12.2 \\
\hline Qalandiah Step4 & 0.61 & 0.58 & 0.66 & 4.12 & 0.85 & 0.58 & 0.78 & 0.5 & 4.8 & 0.86 & 5.53 & 4 & 0.98 & 1.96 & 2.8 \\
\hline Stone Cut Step1 & 0.88 & 4 & 1.74 & 1.2 & 2.87 & 1.54 & 0.57 & 2.5 & 10 & 0.11 & 1 & 6.67 & 0.8 & 8 & 1 \\
\hline Stone Cut Step2 & 0.45 & 1 & 1.18 & 0.33 & 1.47 & 1.7 & 0.65 & 1 & 10 & 0.33 & 1 & 3.75 & 0.85 & 5.82 & 1 \\
\hline Stone Cut Step3 & 1.33 & 1.22 & 1.1 & 4.52 & 2.62 & 1.59 & 1.16 & 3.16 & 5 & 0.93 & 1 & 30 & 2.46 & 15.09 & 12 \\
\hline Stone Cut Step4 & 0.73 & 0.78 & 0.55 & 0.99 & 0.68 & 0.34 & 0.67 & 0.42 & 2.4 & 0.79 & 2.7 & 2.17 & 1.63 & 0.8 & 2.07 \\
\hline Sweanit Step1 & 0.7 & 2.33 & 1.47 & 0.8 & 5.19 & 2.12 & 0.69 & 2.5 & 2 & 0.22 & 1 & 3.33 & 0.44 & 2.5 & 1 \\
\hline Sweanit Step2 & 0.73 & 1 & 0.82 & 0.44 & 2.25 & 1 & 0.44 & 1 & 10 & 0.4 & 1 & 1.75 & 1.04 & 0.65 & 1 \\
\hline Sweanit Step3 & 1.36 & 0.9 & 0.77 & 2.34 & 1.45 & 1.43 & 1.57 & 1.58 & 11 & 0.93 & 1 & 10 & 3.08 & 4.18 & 2 \\
\hline Sweanit Step4 & 0.47 & 0.43 & 0.52 & 0.57 & 0.38 & 0.98 & 0.5 & 1.12 & 4.6 & 0.86 & 3.93 & 0.83 & 1.27 & 0.39 & 1.2 \\
\hline Fawwar Step1 & 0.75 & 2.67 & 1.58 & 1.4 & 12.9 & 2.69 & 0.89 & 2.5 & 0 & 0.5 & $\mathbf{0}$ & 3.33 & 0.92 & 5 & 1 \\
\hline Fawwar Step2 & 0.87 & 0.75 & 1 & 5.44 & 3.94 & 2.5 & 0.94 & 1 & 0 & 1.22 & 0 & 2.5 & 0.94 & 1.76 & 1 \\
\hline Fawwar Step3 & 1.66 & 1.27 & 1.98 & 4.45 & 3.51 & 1.75 & 1.43 & 2.63 & 10 & 1.71 & 6 & 20 & 2.42 & 3.73 & 9.8 \\
\hline Fawwar Step4 & 1.05 & 0.65 & 0.98 & 0.72 & 0.78 & 0.71 & 0.72 & 1.31 & 12.2 & 1.07 & 2.3 & 0.83 & 1.08 & 0.28 & 0.93 \\
\hline Ras Al-Qilt Step1 & 0.81 & 3.33 & 2.11 & 0.8 & 2.1 & 1.31 & 1.13 & 2.5 & 10 & 2.17 & 1 & 1 & 1 & 1.5 & 1 \\
\hline Ras Al-Qilt Step2 & 2.67 & 1 & 1.36 & 0.44 & 0.94 & 1.95 & 1.64 & 1 & 10 & 3.24 & 1 & 0.75 & 0.72 & 0.76 & 1 \\
\hline Ras Al-Qilt Step3 & 1.75 & 0.77 & 0.95 & 1.23 & 0.62 & 1.78 & 4.59 & 1.58 & 5 & 2.71 & 1 & 4 & 1.75 & 1.15 & 1 \\
\hline Ras Al-Qilt Step4 & 0.94 & 0.53 & 1.18 & 0.52 & 0.84 & 1.01 & 0.5 & 1.88 & 1.8 & 0.86 & 0.93 & 0.67 & 1.2 & 0.17 & 0.4 \\
\hline Murashahat step 1 & 0.63 & 3.33 & 1.68 & 1 & 0.84 & 2.31 & 0.98 & 2.5 & 10 & 0.67 & 1 & 1 & 1 & 1 & 1 \\
\hline Murashahat step 2 & 0.86 & 0.75 & 1.04 & 0.44 & 0.36 & 2.4 & 1.02 & 1 & 10 & 0.84 & 1 & 0.75 & 0.74 & 0.59 & 5 \\
\hline Murashahat step 3 & 1.01 & 0.86 & 0.95 & 2.28 & 0.67 & 1.38 & 2.22 & 0.53 & 5 & 0.89 & 1 & 3 & 0.71 & 1.39 & 1 \\
\hline Murashahat step 4 & 1.73 & 1.03 & 1.17 & 1.49 & 1.06 & 4.94 & 1.17 & 2.23 & 1.8 & 3.71 & 0.77 & 0.83 & 0.61 & 0.5 & 0.8 \\
\hline Sultan Step1 & 0.88 & 2.33 & 1.68 & 0.8 & 0.65 & 0.38 & 1.12 & o & $\mathbf{0}$ & 3.39 & 2 & $\mathbf{0}$ & 0.72 & 5 & 0 \\
\hline Sultan Step2 & 3.33 & 7.75 & 1.75 & 1.11 & 1.29 & 2 & 0.25 & $\mathbf{0}$ & $\mathbf{0}$ & 1.05 & 2 & 0 & 0.43 & 43.53 & 0 \\
\hline Sultan Step3 & 0.69 & 0.27 & 0.57 & 0.65 & 0.23 & 0.16 & 0.03 & 1.58 & 1 & 0.21 & 2 & 0 & 0.13 & 1.74 & 0.2 \\
\hline Sultan Step4 & 1.28 & 1.45 & 0.65 & 1.22 & 0.79 & 0.43 & 2.39 & 0.38 & 0.2 & 2.21 & 3.17 & 0.5 & 0.37 & 0.53 & 0.4 \\
\hline
\end{tabular}

$\mathrm{CF}<1$ in white, $1 \leq \mathrm{CF}<3$ light gray, $3 \leq \mathrm{CF}<6$ gary and $\mathrm{CF} \geq 6$ dark black

populated areas. $\mathrm{Zn}, \mathrm{Ag}, \mathrm{Cd}, \mathrm{Hg}, \mathrm{Bi}$, and $\mathrm{B}$ have $\mathrm{CF}$-values greater than six classifying them as highly polluted. When applying the calculation of CF to single steps of the BCR sequential extraction scheme, a more realistic view on the potential impact of the trace metals to the environment is gained. Considering the first two steps of the BCR scheme (exchangeable, reducible) which are the most relevant fractions from which the metals can be released to the 
environment, $\mathrm{Cu}, \mathrm{Pb}, \mathrm{Zn}, \mathrm{Ag}, \mathrm{Sb}$, and $\mathrm{Bi}$ exhibit $\mathrm{CFs}$ greater than six. This can be seen as hints for high risk of pollution by these trace metals.

Acknowledgments The authors would like to acknowledge Dr. Wasim Ali from University of Karlsruhe for his support and the Federal Ministry of Education and Research (BMBF) for funding the $\mathrm{PhD}$ work of the first author. The technical assistance that was provided by the laboratory staff to the Helmholtz Centre for Environmental Research (UFZ) in Magdeburg is greatly acknowledged. The authors also wish to thank the assistance of Othman Sheha, Sami Daraghmah, Ghaleb Bader and Emad Al-Safi, Anwar Zuhluf and Hazem Jumaa'. The constructive comments of an anonymous reviewer are greatly appreciated. Finally, the efforts from Dr. Abed Al-Rahman Tamimi from the Palestinian Hydrological Group (PHG) are appreciated and acknowledged.

Open Access This article is distributed under the terms of the Creative Commons Attribution License which permits any use, distribution, and reproduction in any medium, provided the original author(s) and the source are credited.

\section{References}

American Public Health Association (2000) Standard methods for the examination of water and wastewater, 20th edn. Washington, DC
ARIJ (2007) Applied Research Institute-Jerusalem: status of environment in the West Bank Territories. Palestine

DIN 38414 (1984) German standard methods for the examination of water, waste water and sludge. Beuth Verlag, Berlin

Hokanson L (1980) Ecological risk index for aquatic pollution control, a sedimentological approach. Water Res 14:975-1001. doi:10.1016/0043-1354(80)90143-8

Palestinian Central Bureau of Statistics (2003) Israeli Settlements in the Palestinian territory, annual report 2002. Ramallah, West Bank, Palestine

Palestinian Central Bureau of Statistics (PCBS) (2005) Revised population projection 2005. Ramallah, West Bank, Palestine

Palestinian Water Authority (2009) Data Base and GIS units. West Bank, Ramallah

Pekey H, Karakas D, Ayberk S, Tolun L, Bakoglu M (2004) Ecological risk assessment using trace elements from surface sediments of Izmit Bay (Northeastern Marmara Sea) Turkey. Mar Pollut Bull 48:946-953

Turekian K, Wedepohl K (1961) Distribution of the elements in some major units of the earth's crust. Geol Soc Am Bull 72:175-192

Ure AM, Quevauviller Ph, Muntau H, Griepink B (1993) Speciation of heavy metal in soils and sediments. An account of the improvement and harmonisation of extraction techniques undertaken under the auspices of the BCR of the Commission of the European Communities. Int J Environ Anal Chem 51:135-151 